\title{
Kemampuan Beberapa Spesies Jamur Tanah dalam Mengendalikan Globodera rostochiensis (Woll.) pada Tanaman Kentang
}

\author{
Agusthin Marthin Kalay ${ }^{1 *}$, Sadeli Natasasmita ${ }^{2)}$, Tarkus Suganda²), dan Tualar Simarmata ${ }^{3)}$ \\ 1) Jurusan Budidaya Pertanian, Fakultas Pertanian, Universitas Pattimura, Ambon 97233 \\ 2)Jurusan Hama dan Penyakit Tanaman, Fakultas Pertanian, Universitas Padjadjaran, Bandung 40600 \\ 3) Jurusan Ilmu Tanah Fakultas Pertanian, Universitas Padjadjaran, Bandung 40600
}

Diterima 23-09-2010 Disetujui 03-02-2011

\begin{abstract}
Potatos cyst nematode (Globodera rostochiensis Woll.) in Indonesia has been find for the first time in Malang East Java. This nematode suppress potato growth and caused yield looses up to $70.63 \%$. Examination the ability of soil fungus Fusarium oxysporum TR1, F. solani TR2, F. oxysporum KT1, F. chlamydosporum KT2, F. oxysporum SM1, Paecilomyces lilacinus SM3, and F. chlamydosporum SM4 dalam pengendalian G. rostochiensis againsit G. rostochiensis on susceptible potato has been carried in out the green house, using Randomized Block Design with four replication. Results showed that all of the seven fungi had the capacity to parasite G. rostochiensis. Inoculation of $P$. Iilacinus SM3, F. chlamydosporum SM4, F. oxysporum KT1, and F. oxysporum SM1 decreased female population to $58.56 \%, 59.09 \%, 60.76 \%$, and $61.01 \%$ respectively compared to that without inoculation. While the other fungi only decrease female population up to $50 \%$. The impact of male population reduction was the enhancement of tuber weight of potato. Adult male nematode was not found in this experiment.
\end{abstract}

Keywords: Control, Fusarium sp, Globodera rostochiensis, Nematode, Paecilomyces sp, potato

\section{PENDAHULUAN}

Globodera rostochiensis (Woll.) adalah salah satu spesies nematoda yang menyerang tanaman kentang. Nematoda ini dikenal dengan nama nematoda emas atau golden nematode (Evans et al., 2003), atau nematoda sista kentang (Potato Cyst Nematode, PCN (Turner \& Evans, 1998). Hasil survey yang dilakukan oleh Daryanto (2003), menunjukkan bahwa penyebaran nematoda ini di Indonesia masih terbatas di Propinsi Jawa Timur, Jawa Tengah dan Jawa Barat. Selanjutnya dikemukakan bahwa di Desa Tulung Rejo (Jawa Timur) nematoda ini dapat menurunkan produksi kentang sampai $70,63 \%$.

Globodera rostochiensis dikatakan sebagai nematoda berbahaya karena selain mampu menurunkan produksi kentang, sistanya dapat bertahan hidup pada temperatur tanah $-15^{\circ} \mathrm{C}$ dan pada tanah kering, serta mampu bertahan hidup di dalam tanah selama 30 tahun tanpa keberadaan tanaman inang (Evans et al., 2003). Menghilangkan nematoda ini dari tanah yang telah terinfeksi merupakan sesuatu hal yang tidak mungkin untuk dilakukan. Usaha yang dapat dilakukan adalah

\footnotetext{
*Telp: +6281321396136

Email: marthinkalay@yahoo.com
}

dengan mengendalikan populasinya sampai pada tingkat yang tidak merugikan.

Salah satu cara pengendalian G. rostochiensis yang direkomendasikan di dalam sistem pengendalian hama terpadu (PHT) adalah pemanfaatan agens hayati. Di Indonesia, penggunaan jamur sebagai agens hayati pengendali $G$. rostochiensis secara in-vitro telah dilakukan dengan memanfaatkan jamur Trichoderma $\mathrm{sp}$, Fusarium sp, dan Spicaria sp (Kalay, 2006). Di luar negeri, pemanfaatan jamur terbukti efektif mengendalikan G. rostochiensis. Jaffe et al., (1998), mengemukakan bahwa jamur Cylindrocarpon destruktans, Acremonium strictus dan Fusarium oxysporium mampu menghancurkan sista dan telur $G$ rostochiensis. Uambano dan Kerry (2007), menambahkan bahwa nematoda sista kentang dapat dikendalikan dengan memanfaatkan jamur Pochonia chlamydosporia dan Paecilomyces lilacinus. Di Inggris, pengendalian nematoda sista kentang dilakukan dengan memanfaatkan jamur Paecilomyces lilacinus dan Verticillium chlamydosporium (Daffa, 2003).

Hasil penelitian Kalay et al., (2008), jamur Fusarium oxysporum TR1, F. solaniTR2, F. oxysporum 
KT1, F. chlamydosporum KT2, F. oxysporum SM1, Paecilomyces lilacinus SM3, dan F. chlamydosporum SM4 yang diisolasi dari tanah di beberapa areal pertanaman kentang di Propinsi Jawa Timur, Jawa Tengah, dan Jawa Barat dapat mengendalikan $G$. rostochiensis secara in vitro. Sebuhungan dengan hasil penelitian tersebut, maka penelitian ini dilakukan dengan tujuan untuk menguji kemampuan Fusarium oxysporum TR1, F. solani TR2, F. oxysporum KT1, F. chlamydosporum KT2, F. oxysporum SM1, Paecilomyces lilacinus SM3, dan F. chlamydosporum SM4 dalam mengendalikan G. rostochiensis pada tanaman kentang di Rumah Kaca.

\section{BAHAN DAN METODE}

Kegiatan penyediaan sista G. rostochiensis, dilaksanakan di Laboratorium Hotikulktura dan Aneka Tanaman Balai Pengawasan dan Sertifikasi Benih Tanaman Pangan dan Hortikiltura (BPSBTPH) Dinas Pertanian Propinsi Jawa Barat; sedangkan kegiatan penyiapan media tanam, inokulasi jamur dan penanaman kentang, dilaksanakan di Rumah Kaca Pusat Penelitian Teh dan Kina (PPTK), Gambung, Kabupaten Bandung Jawa Barat, dengan ketinggian tempat $1300 \mathrm{~m}$ di atas permukaan laut.

Rancangan Perlakuan. Percobaan ini dilakukan menggunakan Rancangan Acak Kelompok. Perlakuan yang dicobakan adalah tujuh spesies jamur parasit $G$. rostochiensis yaitu Fusarium oxysporum TR1, F. solani TR2, F. oxysporum KT1, F. chlamydosporum KT2, F. oxysporum SM1, Paecilomyces lilacinus SM3, dan $F$. chlamydosporum SM4, dan satu perlakuan tanpa jamur sebagai kontrol. Setiap perlakuan diulang empat kali. Data pengamatan dianalisis dengan analisis sidik ragam, dan uji lanjut dengan Uji Jarak Berganda Duncan (DMRT) pada á= 0,10 menggunakan program SigmaStat 2,01 (Analitical Software by EZI Installer Version 3,0, Jerman).

Penyediaan sista G. Rostochiensis. Sista diisolasi dari tanah terinfeksi $G$. rostochiensis di desa Sugih Mukti (Jawa Barat). Untuk memperoleh sista, tanah tersebut diekstraksi menggunakan metode Fenwick (Shepherd, 1986). Sista dikumpulkan di gelas Beaker kemudian dibersihkan dengan larutan sodium laurent sulphate (SLES) 0,02\% untuk membebaskan mikrooganisme dan kotoran tanah yang melekat pada sista (Clovis \& Nolan, 1983). Selanjutnya sista disimpan di dalam refrigerator untuk digunakan pada percobaan tahap kedua.

Penyiapan media tanam, inokulasi jamur dan penanaman kentang. Sebagai media tanam digunakan campuran tanah Andisol asal Lembang dan kotoran ayam dengan perbandingan $3: 1(\mathrm{v} / \mathrm{v})$ yang telah disterilkan. Sebanyak $1,75 \mathrm{~kg}$ media tanam dimasukkan ke dalam polibag kemudian ditambahkan 50 sista. Sebanyak $100 \mathrm{ml}$ suspensi jamur diinokulasikan ke dalam $1,75 \mathrm{~kg}$ media tanam di dalam polibag (de Scurrah, 1981), kemudian diinkubasi di dalam rumah kaca selama dua minggu. Selanjutnya media tanam ditanami dengan bibit kentang kultivar Granola dan dipelihara di rumah kaca selama 56 hari (8 minggu).

Inkulan jamur disiapkan dalam bentuk suspensi. Sebanyak $10 \mathrm{ml}$ akuades steril ditambahkan ke dalam satu agar plat kultur jamur, kemudian biomassa jamur dikeruk dari permukaan agar. Suspensi biomassa jamur dipindahkan ke dalam erlen meyer dan dihomogenisasi. Suspensi jamur diencerkan sampai kepadatan $10^{6} \mathrm{spora} / \mathrm{ml}$.

Pengamatan. Pengamatan dilakukan pada hari ke 56 setelah tanam. Variabel respons yang diamati adalah populasi betina dan jantan dewasa $G$. rostochiensis, jumlah dan bobot umbi tanaman kentang. Penentuan jumlah nematoda jantan dewasa dilakukan menggunakan metode Bearmenn (Singh \& Sitaramaiah, 1994), sedangkan jumlah betina dilakukan menggunakan metode Fenwick (Shepherd, 1986). Formula untuk menghitung populasi betina dan jantan dewasa adalah sebagai berikut (Hooper, 1986):

$\mathrm{P}=\mathrm{N} \times \frac{100+\mathrm{Y}}{100} \times \frac{200}{\mathrm{Z}}$ nematoda/200 g tanah kering konstan

Keterangan :

$\mathrm{P}=$ jumlah nematoda per $200 \mathrm{~g}$ tanah kering konstan

$\mathrm{N}=$ jumlah nematoda yang terekstraksi dari $100 \mathrm{~g}$ tanah basah

$\mathrm{Y}=$ bobot air per $100 \mathrm{~g}$ tanah kering

$Z$ = bobot tanah basah yang digunakan untuk mengekstraksi nematoda (100 g).

\section{HASIL DAN PEMBAHASAN}

Populasi betina dan jantan dewasa $G$. rostochiensis pada media tanam. Inokulasi jamur $F$. oxysporum TR1, F. solani TR2, F. oxysporum KT1, F. chlamydosporum KT2, F. oxysporum SM1, P. lilacinus 
SM3, dan F. chlamydosporum SM4 menurunkan populasi betina $G$. rostochiensis secara signifikan dibandingkan dengan kontrol (Tabel 1). Pada Tabel tersebut terlihat bahwa ketujuh jamur yang diuji mampu menurunkan populasi dengan persentase yang bervariasi berkisar 46,82\%-61,01\%. Penurunan tertinggi terjadi pada $F$. oxysporum SM1 dan menunjukkan perbedaan yang signifikan dengan semua jamur uji lainnya.

Semua jamur yang diuji dapat mengendalikan $G$. rostochiensis di dalam tanah karena dari hasil penelitian sebelumnya hifa dari semua jamur yang diuji dapat menginfeksi sista, telur, dan J2 G. rostochiensis (Kalay, 2007). Singh dan Sitaramaiah (1994), menambahkan bahwa hifa F. oxysporum dapat melakukan penetrasi ke dalam sista dan telur Heterodera sp, sedangkan Khan et al., (2006), mengemukakan bahwa hifa $P$. lilacinus dapat melakukan penetrasi ke dalam sista, telur dan betina Heterodera avenae. Dengan adanya penetrasi hifa ke dalam sista dan telur, perkembangan juvenil terhambat dan akhirnya mati.

Selain melalui cara penetrasi hifa, diduga jamur uji memproduksi enzim dan senyawa toksin yang dapat menghambat perkembangan $G$ rostochiensis. Menurut Singh et al., (1999) dan Khan et al., (2006), Fusarium dan Paecilomyces dapat memproduksi enzim kitinase, proteinase, dan lipase. Menurut Mercer et al., (1992), enzim proteinase dan lipase dapat menghidrolisis protein dan lipid pada kutikula juvenil, telur dan jantan dewasa nematoda sehingga terjadi lisis, Sedangkan kerusakan kitin pada kulit telur nematoda oleh kitinase menyebabkan penetasan prematur dan $\mathrm{J} 2$ sehat yang dihasilkan menjadi sedikit. Mian et al., (1982), menambahkan bahwa meningkatnya aktivitas kitinase dapat merusak kandungan kitin pada kulit telur dan terjadi peningkatan konsentrasi amoniak akibat hidrolisis kitin. Amoniak merupakan nematisida yang dalam konsentrasi tinggi berpengaruh menekan perkembangan nematoda.

Beberapa hasil penelitian menunjukkan bahwa Fusarium memproduksi senyawa toksin seperti moniliformis, fusarenon, neosolaniol yang dapat mengurangi penetasan telur $M$. incognita (Ciancio et al., 1988). Toksin T2, verrucarine A; dan cytochalasin $B$ dapat menurunkan viabilitas juvenil $M$. javanica (Ciancio, 1995), 4,15-diacetylnivaleno dan diacetoxyscirpeno/ dapat menghambat penetasan dan pergerakan M. incognita (Nitao et al., 2001; dikutip Chitwood, 2002). Senyawa toksin yang dihasilkan Paecilomyces adalah brefeldine A (Wang et al., 1999), ergosterol peroxide dan acetoxyscirpenediol (Nam et al., 2001), dan dipicolinic acid (Asaff et al., 2005), namun peranan toksin ini terhadap nematoda belum diketahui dengan jelas.

Penghambatan perkembangan G. rostochiensis dapat disebabkan karena hifa Fusarium menginvasi sinsitium yang dibentuk oleh nematoda sebagai tempat makan di dalam akar kentang sehingga sinsitium menjadi rusak. Kerusakan sinsitium oleh Fusarium menurut Turner dan Evans (1998), bukan saja akibat invasi hifa, tetapi juga karena metabolit toksin yang dikeluarkan jamur, yang ditandai terbentuknya kristal yang terbentuk di plastid sinsitium. akibat dari rusaknya sinsitium maka perkembangan juvenil menjadi terhambat bahkan terhenti.

Nematoda jantan dewasa tidak ditemukan baik pada tanah yang diinokulasi maupun pada tanah yang tidak diinokulasi jamur (kontrol). Ketiadaan ini dapat disebabkan oleh (1) tingkat kesuburan tanah; (2) kemampuan hidup setelah keluar dari akar; dan (3) kematian setelah kawin. Kesuburan tanah merupakan faktor penentu menurunnya populasi nematoda jantan.

Tabel 1. Pengaruh inokulasi jamur terhadap populasi betina G. rostochiensis pada media tanam

\begin{tabular}{lcc}
\hline \multicolumn{1}{c}{ Spesies jamur } & \multicolumn{1}{c}{ Populasi betina G. rostochiensis } \\
\cline { 2 - 3 } & $\begin{array}{c}\text { Jumlah } \\
\text { (per 200 g tanah kering konstan) }\end{array}$ & $\begin{array}{c}\text { Penurunan } \\
(\%)\end{array}$ \\
\hline Tanpa jamur (Kontrol) & $8,97 \mathrm{~h}$ & - \\
F. oxysporum TR1 & $4,63 \mathrm{e}$ & 48,36 \\
F. solani TR2 & $4,66 \mathrm{f}$ & 48,08 \\
F. oxysporum KT1 & $3,52 \mathrm{~b}$ & 60,76 \\
F. chlamydosporum KT2 & $4,77 \mathrm{~g}$ & 46,82 \\
F. oxysporum SM1 & $3,49 \mathrm{a}$ & 61,01 \\
P. lilacinus SM3 & $3,72 \mathrm{~d}$ & 58,56 \\
F. chlamydosporum SM4 & $3,67 \mathrm{c}$ & 59,09 \\
\hline
\end{tabular}

Keterangan: Angka yang diikuti oleh huruf yang berbeda pada satu kolom menunjukkan berbeda menurut uji DMRT pada á = 0,10 
Media tanam yang digunakan mengandung unsur hara $\mathrm{N}$, $\mathrm{P}$, dan $\mathrm{K}$ cukup tinggi yaitu 8,21\% C; 0,80\% N; 1,084 $\mathrm{mg} \mathrm{kg}^{-1} \mathrm{P}_{2} \mathrm{O}_{5}$; dan 2,366 mg kg-1 $\mathrm{K}_{2} \mathrm{O}$. Menurut Turner dan Evans (1998), ketersediaan hara yang tinggi di dalam tanah menyebabkan nematoda betina $G$. rostochiensis terbentuk lebih banyak daripada nematoda jantan. Nematoda jantan hanya terbentuk pada lingkungan yang krisis unsur hara. Selain itu, secara genetis, nematoda jantan hanya bertahan kurang lebih 10 hari setelah keluar dari akar (Dropkin, 1989). Di dalam selang waktu tersebut jika nematoda jantan kawin maka nematoda tersebut akan segera mati.

Jumlah dan bobot umbi kentang. Inokulasi jamur F. oxysporum TR1, F. solani TR2, F. oxysporum KT1, F. chlamydosporum KT2, F. oxysporum SM1, P. lilacinus SM3, dan F. chlamydosporum SM4 tidak berpengaruh secara signifikan terhadap jumlah umbi, dan hanya mampu meningkatkan jumlah umbi sebesar 5,56\%-11,11\%. Namun meningkatkan bobot umbi secara signifikan sebesar 22,39\%-40,41\% (Tabel 2).

Pengaruh terhadap bobot umbi merupakan efek tidak langsung dari penghambatan perkembangan $\mathrm{G}$. rostochiensis oleh jamur. Penghambatan ini diperlihatkan antara lain dengan menurunnya populasi nematoda betina di dalam media tanam.

Infeksi J2 G. rostochiensis pada akar kentang akan menginduksi terbentuknya tempat makan berupa sinsitium (Hussey et al., 2002), sehingga terjadi perubahan fisiologi, morfologi, dan fungsi sel tanaman (Gheysen \& Fenoll, 2002). Terbentuknya sinsitium dalam akar akan mempengaruhi penyerapan dan translokasi air dan unsur hara ke bagian tajuk seperti terlihat pada hasil penelitian de Ruijter dan Haverkort (1999), menjelaskan bahwa konsentrasi N, P dan K daun pada tanaman yang terinfeksi Globodera spp secara umum berkurang. Trudgill et al., (1998), menambahkan bahwa infeksi J2 Globodera berpengaruh terhadap pertumbuhan akar kentang dan pada tingkat infeksi berat, sistem perakaran lebih sedikit karena berkurangnya jumlah akar lateral sehingga akar tidak efisien menyerap air dan hara. Fenomena di atas menyebabkan terganggunya proses fisiologis tanaman sehingga pertumbuhan dan hasil tanaman berkurang.

Kehadiran Fusarium dan Paecilomyces bersama G. rostochiensis pada tempat dan waktu yang sama, akan memicu interaksi antagonis. Mekanisme antagonis yang terjadi adalah melalui penetrasi hifa, produksi enzim dan toksin, dan invasi sinsitium oleh jamur uji sehingga perkembangan G. rostochiensis menjadi terhambat bahkan terhenti, yang ditujukkan dengan jumlah populasi betina yang rendah (Tabel 1).

Pada Tabel 2 dapat terlihat juga bahwa P. lilacinus SM3 relatif lebih mampu meningkatkan bobot umbi sebesar $40,41 \%$ dibandingkan dengan F. oxysporum TR1, F. solani TR2, F. oxysporum KT1, F. chlamydosporum KT2, F. oxysporum SM1, dan F. chlamydosporum SM4. Peningkatan ini tidak sejalan dengan kemampuannya dalam menurunkan populasi betina G. rostochiensis yaitu sebesar 58,56\%, lebih rendah dari F. oxysporum SM1, F. oxysporum KT1, dan F. chlamydosporum SM4 yang mampu menurunkan populasi betina masing-masing sebesar $61,01 \%$; 60,76\%; dan 59,09\% (Tabel 1).

Tingginya bobot umbi setelah aplikasi P. lilacinus dibandingkan dengan jamur uji lainnya karena $P$. lilacinus menghasilkan sejumlah enzim yang berperan dalam degradasi bahan organik tanah. Sejumlah enzim ini berperan dalam siklus unsur hara di dalam tanah seperti siklus karbon, nitrogen dan fosforus

Tabel 2. Pengaruh inokulasi jamur terhadap jumlah umbi dan bobot umbi per tanaman kentang yang ditanam pada tanah terinfestasi sista G. rostochiensis

\begin{tabular}{lcccc}
\hline \multicolumn{1}{c}{ Spesies Jamur } & \multicolumn{2}{c}{$\begin{array}{c}\text { Jumlah umbi } \\
\text { Bobot umbi }\end{array}$} \\
\cline { 2 - 5 } & Jumlah & $\begin{array}{c}\text { Peningkatan } \\
(\%)\end{array}$ & $\begin{array}{c}\text { Bobot } \\
(\mathrm{g})\end{array}$ & $\begin{array}{c}\text { Peningkatan } \\
(\%)\end{array}$ \\
\hline Tanpa jamur (Kontrol) & $4,50 \mathrm{a}$ & - & $60,22 \mathrm{a}$ & - \\
F. oxysporum TR1 & $4,75 \mathrm{a}$ & 5,58 & $73,70 \mathrm{~b}$ & 22,39 \\
F. solani TR2 & $4,75 \mathrm{a}$ & 5,56 & $74,36 \mathrm{c}$ & 23,48 \\
F. oxysporum KT1 & $4,75 \mathrm{a}$ & 5,56 & $76,75 \mathrm{~d}$ & 27,45 \\
F. chlamydosporum KT2 & $5,00 \mathrm{a}$ & 11,11 & $79,42 \mathrm{e}$ & 31,90 \\
F. oxysporum SM1 & $5,00 \mathrm{a}$ & 11,11 & $81,46 \mathrm{~g}$ & 35,29 \\
P. lilacinus SM3 & $4,75 \mathrm{a}$ & 5,56 & $84,55 \mathrm{~h}$ & 40,41 \\
F. chlamydosporum SM4 & $4,75 \mathrm{a}$ & 5,56 & $79,69 \mathrm{f}$ & 32,33 \\
\hline
\end{tabular}

Keterangan: Angka yang diikuti oleh huruf yang berbeda pada satu kolom menunjukkan berbeda menurut uji DMRT pada á = 0,10 
(Atlas \& Bartha, 1993). Kotlova et al., (2007), menemukan senyawa serine proteinase ektraseluler pada filtrat medium kultur jamur P. lilacinus. Selanjutnya dikemukakan juga bahwa senyawa ini dapat menghidrolisis protein, gugus $p$-nitroanilide yang ada di tripeptida, dan norleucine, leucine dan phenylalanie. Gupta et al., (1993), mengemukakan bahwa P. lilacinus dapat memperlihatkan aktivitas enzim hidrolitik seperti polisakaridase, protease, dan kitinase. Degradasi substrat protein akan meningkatkan konsentrasi nitrogen tersedia di dalam tanah yang akan dimanfaatkan oleh tanaman bagi pertumbuhannya. Hidrolisis polisakarida di dalam tanah akan menghasilkan sumber karbon seperti gula sederhana dan asam organik untuk mikroorgnisme heterotrof. Dengan demikian secara tidak langsung, produksi enzim oleh $P$. lilacinus akan berperan dalam pertumbuhan tanaman.

\section{KESIMPULAN}

Jamur tanah $F$. oxysporum TR1, F. solani TR2, $F$. oxysporum KT1, F. chlamydosporum KT2, F. oxysporum SM1, P. lilacinus SM3, dan F. chlamydosporum SM4 mampu mengendalikan populasi $G$. rostochiensis. Inokulasi $P$. lilacinus SM3, F. chlamydosporum SM4, F. oxysporum $\mathrm{KT} 1$, dan F. oxysporum SM1 masingmasing menurunkan populasi betina sebesar $58,56 \%$, $59,09 \%, 60,76 \%$, dan $61,01 \%$ dibandingkan dengan tanpa diinokulasi jamur. Sedangkan spesies jamur lainnya hanya menurunkan populasi betina di bawah $50 \%$. Nematoda jantan dewasa tidak ditemukan baik pada tanah yang diinokulasi maupun pada tanah yang tidak diinokulasi jamur.

Penurunan populasi betina berdampak pada peningkatan bobot umbi. Namun, tidak ada satu spesies jamur yang paling unggul dalam menurunkan populasi betina sekaligus meningkatkan bobot umbi. Jamur $F$. oxysporum SM1 lebih unggul dalam menurunkan populasi betina $G$. rostochiensis, sedangkan $P$. lilacinus SM3 lebih unggul dalam meningkatkan bobot umbi kentang dibandingkan dengan jamur uji lainnya.

\section{UCAPAN TERIMA KASIH}

Terima kasih kepada Kepala Balai Pengawasan dan Sertifikasi Benih Tanaman Pangan dan Hortikultura (BPSBTPH) Departemen Pertanian Propinsi Jawa Barat dan Kepala Pusat Penelitian Teh dan Kina (PPTK),
Gambung, Kabupaten Bandung Jawa Barat atas kesediaan memberikan ijin penggunaan fasilitas di Laboratorium dan Rumah Kaca untuk pelaksanaan penelitian.

\section{DAFTAR PUSTAKA}

Asaff, A., Cerda-Garcia-Rojas, C. \& de la Torre, M. 2005. Isolation of dipicolonic acid as an insecticidal toxin from Paecilomyces fumosoroseus. Appl. Microbiol. Biotech 68: 542-547.

Atlas, R.M. \& Bartha, R. 1993. Microbial ecology. Third Edition. Canada: The Benjamin/Cummings Publishing Company, Inc.

Aumbano, N. \& Kerry, B.R. 2007. Nemathopagous fungi and organic amendments can be applied together in managing root-knot and potato cyst nematodes. Africans Crops Science Conference Prossiding, 8: 1079-1082.

Chitwood, D.J. 2002. Phytochemical based strategies for nematode control. Annu. Rev. Phytopathol 40: 221-249.

Ciancio, A. 1995. Observation on the nematicidal properties of some mycotoxins. Fundamental and Applied.Nematology, 18: $451-454$

Ciancio, A., Logrieco, A., Lamberti, F. \& Bottalico, A. 1988. Nematicidal effect of some fusarium toxin. Nematologia Mediterranean 16: 137-138.

Clovis, C.J. \& Nolan, R.A. 1983. Fungi associated with cysts, eggs and juveniles of the golden nematodes (Globodera rostochiensis) in Newfoundland. Nematologia 29: 245-365.

Daryanto, 2003. Status penyebaran dan kerugian nematoda sista kuning pada tanaman kentang. Makalah disampaikan pada Lokakarya Nematoda Sista Kuning. Yogyakarta, 11-12 Desember 2003.

DAFFA (Departmen of Agricultura, Fisheries dan Forestri Australia). 2003. Potato cyst nematode. Http:// www.affa.gov.au/content/schools/rl/8071.htm [14 Oktober 2003].

de Ruijter, F.J. \& Haverkort, A.J. 1999. Effects of potatoscyst nematode (Globodera pallida) and soil $\mathrm{pH}$ on root growth, nutrient uptake and crop growth of potato. European Journal of Plant Pathology 105: 61-76.

de Scurrah, M.M. 1981. Evaluating resistance to potato cyst nematodes. de la Papa: International Potato Center (CIP).

Dropkin, V.H. 1989. Introduction to plant nematology. Secont Edition. New York: John Wiley and Sons.

Evans, K., Webster, R., Barker, A., Halford, P. \& Russell, M. 2003. Mapping infestation of potatos cyst nematodes and the potential for spatially varying application of nematodes. Hert: IACR-Rothamsted. Harpenden.

Gheysen, G. \& Fenoll, C. 2002. Gene expression in nematode feeding sites. Annu. Rev. Phytopathol. 40: 124-168.

Gupta, S.C., Leathers, T.D. \& Wicklow, D.T. 1993. Hydrolytic enzymes secreted by Paecilomyces lilacinus cultured on sclerotia of Aspergillus flavus. Journal Apllied Microbiology and Biotechnology 39: 99-103.

Hooper, D.J. 1986. Extraction of free-living stages from soil. Di dalam: Southey, J.F. (ed). Laboratory methods for work with plant and soil nematodes. London: Ministri of Agriculture, Fishereies and Food.

Hussey, R.S., David, E.L. \& Baum, T.J. 2002. Secrets in secretions: Genes that control nematode parasit of plants. Braz J. Plant Physiol 14: 183-194.

Jaffee, B.A., Ferris, H. \& Scow, K.M. 1998. Nematoda-trapping fungi in organic and conventional trapping systems. Phytopathology, 88: 244-350.

Kalay, A.M. 2006. Pengujian tiga spesies jamur sebagai agens hayati pengendali Globodera rostochiensis (Woll.). J. Peng. Wil. 2: 116-121.

Kalay, A.M. 2007. Cara penyerangan beberapa spesies jamur tanah terhadap berbagai stadia Globodera rostochiensis (Woll.). Jurnal Agrista, 11: 68-72.

Kalay, A.M., Natasasmita, S., Suganda, T. \& Simarmata, T. 2008. Uji parasitik beberapa spesies jamur tanah terhadap 
Globodera rostochiensis (Woll) Secara In Vitro. Jurnal Natur Indonesia 10: 73-75.

Khan, A., Williams, K.L. \& Nevalainen, H.K.M. 2006. Infection of plant-parasitic nematodes by Paecilomyces lilacinus and Monacrosporium lysipagum. BioControl 51: 659-678.

Kotlova, E., Ivanova, N., Yusupova, M., Voyushina, T., Ivanushkina, N. \& Chestukhina, G. 2007. Thiol-dependent serine proteinase from Paecilomyces lilacinus: Purification and catalytic properties. Biochemintry 72: 117-123.

Mercer, C.F., Greenwood, D.R. \& Grant, J.L. 1992. Effect of plant and microbial chitinases on the eggs and juveniles of Meloidogynehapla Chitwood. Nematologica 8: 227-236.

Mian, J.H., Godoy, G., Shelby, R.A., Rodriguez-Kabana, R. \& Morgan-Jones, G. 1982. Chitin amendments for control of Meloidogyne arenaria in infested soil. Nematropica 12: 7184.

Nam, K.S., Jo, Y.S., Kim, Y.H., Hyn, J.W. \& Kim, H.W. 2001. Cytotoxic activities of acetoxyscipenediol and ergosterol peroxide from Paecilomyces tenuipes. Life Sci 69: 229-237.

Shepherd, A.M. 1986. Ekstraction and estimation of cyst nematodes. Di dalam Southey J.F. (ed) Laboratory methods for work with plant and soil nematodes. London: Ministri of agriculture, fishereies and Food.

Singh, P.P., Shin, Y.C.C., Park, S. \& Chung, Y.R. 1999. Biological control of Fusarium wilt of cucumber by chitinolytic bacteria. Phytopathology 89: 92-99.

Singh, R.S. \& Sitaramaiah, K. 1994. Plant pathogens the nematodes. New York: International Science Publisher.

Trudgill, D.L., Evans, K. \& Philips, M.S. 1998. Potato cyst nematodes: Damage, mechanisme and tolerance in the potatos. Di Dalam Marks, R.J dan Brodie, B.B (ed). Potato cyst nematodes: Biology, distribution and control, 117-134 pp. New York: CAB International.

Turner, S.J. \& Evans, K. 1998. The Original, global distribution and biology of PCN (Globodera rostochiensis (Woll) and Globodera pallida (Stone). Di dalam Marks, R.J \& Brodie, B.B (ed). Potato cyst nematodes: Biology, distribution and control, 7-26 pp. NewYork: CAB International.

Wang, X., Meyers, D.,Yan, Y., Baum, T., Smant, G., Hussey, R.S. \& Davis, E.L. 1999. In planta localization of a â-1,4endoglucanase secreted by Heterodera glycines. Mol. PlantMicrobe Interac 12: 64-67. 